\title{
Identification and enumeration of weed seeds in chopped maize being transported for silage
}

\author{
T.K. James, C.A. Dowsett and M.R. Trolove \\ AgResearch, Ruakura Research Centre, Private Bag 3123, Hamilton 3240, New Zealand \\ Corresponding author: trevor.james@agresearch.co.nz
}

\begin{abstract}
Maize silage is an important dairy feed supplement and is often transported many kilometres from where it is grown to where it is ensiled. Debris has been observed to blow from the transporting trucks as they travel along the road, raising concerns about the spread of weeds. In this study, trucks carrying freshly chopped maize were intercepted as they departed the field and samples from inside and outside the loaded crate were collected and analysed for weed seeds. Seeds from 15 weed species were found in numbers up to 1300 seeds/kg of freshly chopped maize. Generally, more seed was found in trucks collecting from the headland area compared with the main crop area, and additionally in the first year there was more debris on the outside of the headland trucks. Some mitigating practices to reduce the potential for dispersal of weed seeds in chopped maize are discussed.
\end{abstract}

Keywords weed seeds, maize silage, yellow bristle grass, Setaria pumila.

\section{INTRODUCTION}

Maize silage has become an important feed supplement for dairy farms. Maize is grown as a summer crop from September until March. For the $2013 / 14$ season 56,391 ha of maize was grown for silage in New Zealand averaging 20,282 kg dry matter per ha (AIMI 2015). The majority of this maize for silage is grown by specialist contractors on land separate from its final destination. Most commonly it is transported between sites in trucks equipped with a specialised crate. These trucks collect the silage either by following behind the maize chopper for the first (headland) swath, or beside the maize chopper for the rest of the field (main crop). During this procedure some of the chopped maize is deposited on the outside of the transporting truck. The debris from the outside of these trucks as well as chopped maize from within the crate, if the load is not covered, is frequently observed blowing from these trucks as they travel along the road. This has raised concerns with many farmers and regional councils about the spread of weed seed, particularly yellow bristle grass (Setaria pumila) along the roadside.

The aim of this study was to quantify the amount of debris present on the outside of trucks transporting maize silage before they left the field and to determine how much weed seed was present in both the debris on the outside of the trucks as well as in the chopped maize sampled from within the trucks crate.

\section{MATERIALS AND METHODS \\ Sampling the trucks}

On 28 March 2013 eight trucks were sampled. On 10 April 2014 six further trucks were sampled. Immediately on leaving the maize field the trucks were stopped on a large sheet of black polythene and the debris from the outside of the truck was removed by three people using a combination of brooms, brushes and compressed air guns. 
In 2013, four vehicles sampled were from the headland and four from inside the main crop. In 2014, three were from the headland and three from inside the main crop. In 2013 this procedure averaged $5 \mathrm{~min}$ for trucks from the interior of the field and $7 \mathrm{~min}$ for those from the headland. Also at this time, five grab samples $(500-800 \mathrm{~g})$ were collected at random from the top $50 \mathrm{~mm}$ of the loaded crate to obtain an estimate of the seed loading in debris that might be blown off during transport. After the departure of the trucks all the debris on the polythene was collected, bagged and weighed. All samples were returned to the laboratory for further processing. Trucks from the same contractor (John Austin Ltd) were used in both years but there were procedural changes in the driving methods between the two years.

\section{Identification and enumeration of weed seeds}

The fresh samples were weighed and then laid out on benches in the glasshouse to air dry. Once dry, the samples were thoroughly shaken to ensure the weed seeds had not adhered to the maize and then were dry sieved through $4 \mathrm{~mm}$ and $2 \mathrm{~mm}$ sieves to remove the bulk of the maize silage material. In 2013, the weed seeds were separated by hand under a microscope and identified from the seed atlas (James et al. 2012) and then counted. The efficacy of the hand separation was evaluated by taking 20 of the samples after the seed was removed by hand, soaking the remaining matter in water, then laying it out on the glasshouse bench to see if there were missed seeds that would germinate. For the grab samples the whole sample was processed, but the larger samples from the outside were subsampled by repeated halving after thorough mixing. For these, from one to seven subsamples of about $100 \mathrm{~g}$ were processed.

In 2014, after passing through a $4 \mathrm{~mm}$ sieve, the weed seeds were separated with a Clipper Office Tester (Clipper Separation Technologies, A.T. Ferrell Company, Bluffton Indiana, USA). This device uses a large and a small screen to trap the seed then utilises a fan to further separate the material according to mass. Individual seeds were then identified and counted by hand under a microscope.

The debris weights collected from the outside of the truck (Table 1 ) were positively skewed, and were $\log$ transformed to normalise distribution prior to analysis using ANOVA. Plots of the residuals and the fitted values confirmed the normality assumption to be valid for the transformed data. The seed number data were analysed in three parts. Firstly, the frequency of a seed being present in a sample was determined by fitting binomial data and fitting a generalised linear model (glmer). Secondly, if there were seeds present, another generalised linear model was fitted to identify significant differences between the number of seeds for the individual species. Lastly, the seed totals were analysed using ANOVA after the seed count totals were normalised by square root transformation. The data were analysed using $\mathrm{R}$ (ver. 3.0.2) statistical analysis software (R Foundation for Statistical Computing, Vienna, Austria).

\section{RESULTS}

The evaluation of the efficacy of hand separating seed showed the method to be highly effective. In 12 of the 20 samples no seeds germinated and in the remaining eight samples the number of seeds that germinated was small $(<3 \%)$ and generally in proportion to the 'found' seed, so no corrections were required for 'unfound' seed.

The trucks collecting chopped maize from the headland had significantly more debris on the outside compared with trucks collecting from the main crop area of the field in 2013 (Table 1). Although the trucks were configured differently, there was only limited places on the crates where debris could be trapped and it was observed the large differences between the headland and main crop trucks were due to the large amount of debris removed from the cabs of the headland trucks. There was no significant difference between the two areas in 2014, but the amount of debris collected in this year was significantly less than that collected in 2013.

In 2013, seeds of nine weed species were found in the chopped maize samples collected from the top of the crate and 15 weed species from the debris on the outside of the trucks (Table 2). As well as more species being found in samples taken from the outside debris, most species were also found with greater regularity and in greater numbers. The most abundant seeds found, on both inside 
and outside, were that of fathen followed by yellow bristle grass and barnyard grass. Average number of seeds in the freshly chopped maize was $256 / \mathrm{kg}$ for the samples collected from the inside of the crates and $802 / \mathrm{kg}$ from the debris on the outside.

Results from 2014 show fewer weed species and fewer seeds present both inside and on the outside of the sampled trucks (Table 3). Many of the eight species found were in low numbers but yellow bristle grass and summer grass were found more frequently in outside samples than inside samples and in greater numbers. Frequency of occurrence for fathen was not significant between the inside and outside samples, but the number of seeds present was greater on the outside. Black nightshade was only found on the outside of the trucks.

When the seed numbers from the eight trucks sampled in 2013 (Table 2) were further divided into the four trucks that filled their crates from the main crop area and the four that filled their crates from the headland area, it was found that the trucks from the headland had both more weed species as well as more seeds (Table 4). For yellow bristle grass, barnyard grass and black nightshade, there were significantly more seeds $(\mathrm{P}<0.05)$ in the samples from the headland irrespective of

Table 1 Amount of debris ( $\mathrm{kg}$ fresh weight) collected from the outside of the trucks from the main crop area compared with trucks from the headland in 2013 and 2014.

\begin{tabular}{lcrc}
\hline Year & Main crop & Headland & P-value \\
\hline 2013 & 6.203 & 16.145 & 0.04 \\
2014 & 2.183 & 1.697 & ns \\
P-value & 0.024 & 0.005 & \\
\hline
\end{tabular}

Table 2 Average number of seeds per kg of freshly chopped maize found in the grab samples from the top of the load (inside) compared with the number found in the debris on the outside of the eight trucks sampled in 2013.

\begin{tabular}{llrrc}
\hline Common name & Botanical name & Inside $^{1}$ & Outside $^{2}$ & P-value \\
\hline Yellow bristle grass & Setaria pumila & $39(19)$ & $119(17)$ & 0.006 \\
Barnyard grass & Echinochloa crus-galli & $12(24)$ & $107(17)$ & 0.023 \\
Summer grass & Digitaria sanguinalis & $37(19)$ & $33(18)$ & 0.002 \\
Smooth witchgrass & Panicum dichotomiflorum & $3(17)$ & $3(15)$ & 0.007 \\
Fathen & Chenopodium album & $102(25)$ & $320(18)$ & 0.010 \\
Black nightshade & Solanum nigrum & $25(12)$ & $40(16)$ & 0.001 \\
Willow weed & Persicaria maculosa & $21(24)$ & $71(17)$ & 0.014 \\
Beggars' ticks & Bidens frondosa & $13(12)$ & $66(12)$ & 0.020 \\
Broad-leaved dock & Rumex obtusifolius & $4(22)$ & $11(16)$ & 0.002 \\
Redroot & Amaranthus powellii & 0 & $16(13)$ & - \\
Thorn apple & Datura stramonium & 0 & $12(6)$ & - \\
Paper birch & Betula pendula & 0 & $1(5)$ & - \\
Ryegrass & Lolium spp. & 0 & $1(6)$ & - \\
Rice grass & Microlaena stipoides & 0 & $1(2)$ & - \\
Paspalum & Paspalum dilatatum & 0 & $1(4)$ & - \\
\hline
\end{tabular}

${ }^{1}$ For 'Inside' data the number in brackets is the number of samples in which these seeds were found, out of 40 in total.

${ }^{2}$ For 'Outside' data the number in brackets is the number of samples in which these seeds were found, out of 18 in total.

${ }^{3}$ Significance of the differences in frequency of occurrence in a subsample. 
whether the sample was taken from inside the crate or from the outside of the truck. However, in the headland samples there were significantly $(\mathrm{P}<0.05)$ more seeds in those collected from outside the truck compared with those from within. For fathen the samples taken from the outside of the truck had significantly $(\mathrm{P}<0.05)$ more seeds than those collected from the corresponding harvest location but from inside the truck. Beggars' ticks was only found on trucks being filled from the headland area. In total, significantly $(\mathrm{P}<0.05)$ more seeds were found on the outside of the tucks filling from the headland compared to either the outside of the trucks from the main crop or from the samples taken from inside the crates filled from either area (Table 4).

When the data for 2014 were further separated into trucks from the headland and trucks from the main crop area, it was found that significantly $(\mathrm{P}<0.05)$ more seeds of yellow bristle grass and summer grass were present in the outside samples from the headland (Table 5). For black nightshade, fathen and willow weed the converse was true. In 2014, there were significantly $(\mathrm{P}<0.016)$ more seeds in the outside samples, both from the headland and main crop areas, compared with the samples taken from the inside of the crates.

\section{DISCUSSION}

In 2013 most of the debris found on the outside of the trucks was found on the cab roof. When the headland is being harvested, the receiving truck must drive behind the chopper and if the driver fails to follow at the correct distance then large amounts of the chopped maize is deposited on the roof. When the main crop area is harvested, the receiving truck drives beside the chopper and very little debris lands on other parts of the trucks. In 2014, after the first year's results were presented to the collaborators, John Austin Ltd, one of Waikato's major agricultural contractors, their truck drivers took greater overall care and in the headland areas they managed to avoid having large deposits of debris on the cab roof. Thus, in 2014, the main source of debris collected from the outside of the trucks came from the angle bracing and similar, narrow, shelf-like catchments on the sides of the trucks crate, as was the case for the main crop area samples in 2013. The simple solution of more cautious driving alone could result in up to 10,000 fewer seeds being blown off each truck as it travels along the road. Of these seeds 1800 are of the very troublesome yellow bristle grass, which has dispersed throughout most of the North Island dairying regions over the past 15 years and has the potential to spread through most of New Zealand (James et al. 2009; Lamoureaux \& Bourdôt 2014).

In the present study, samples collected from the outside of the trucks routinely had higher numbers of seeds than the grab samples taken from inside the crate of the same vehicles. The most likely

Table 3 Number of seeds per kg of freshly chopped maize found in the grab samples from the top of the load (inside) compared with the number found in the debris on the outside of the truck (outside) in 2014.

\begin{tabular}{llccc}
\hline Common name & Botanical name & Inside $^{1}$ & Outside $^{2}$ & P-value $^{3}$ \\
\hline Yellow bristle grass & Setaria pumila & $1(6)$ & $39(7)$ & 0.004 \\
Barnyard grass & Echinochloa crus-galli & 0 & $3(5)$ & - \\
Summer grass & Digitaria sanguinalis & $0(3)$ & $298(6)$ & 0.005 \\
Smooth witchgrass & Panicum dichotomiflorum & $4(9)$ & $2(2)$ & $\mathrm{ns}$ \\
Fathen & Chenopodium album & $4(22)$ & $192(7)$ & $\mathrm{ns}$ \\
Black nightshade & Solanum nigrum & 0 & $101(5)$ & - \\
Willow weed & Persicaria maculosa & 0 & $35(7)$ & - \\
Broad-leaved dock & Rumex obtusifolius & 0 & $5(4)$ & - \\
\hline
\end{tabular}

${ }^{1}$ For 'Inside' data the number in brackets is the number of samples in which these seed were found, out of 30 total.

${ }^{2}$ For 'Outside' data the number in brackets is the number of samples in which these seed were found, out of 18 total.

${ }^{3}$ Significance of the differences in frequency of occurrence in a subsample. 
Table 4 Number of seeds per kg of freshly chopped maize found in the samples collected from trucks being filled from the headland of the crop compared with those from the main crop area in 2013.

\begin{tabular}{|c|c|c|c|c|}
\hline \multirow[b]{2}{*}{ Common name } & \multicolumn{2}{|c|}{ Inside $^{1}$} & \multicolumn{2}{|c|}{ Outside $^{2}$} \\
\hline & Main crop & Headland & Main crop & Headland \\
\hline Yellow bristle grass & 2 & 76 & 28 & 210 \\
\hline Barnyard grass & 4 & 20 & 8 & 206 \\
\hline Summer grass & 61 & 12 & 25 & 42 \\
\hline Smooth witchgrass & 4 & 2 & 1 & 6 \\
\hline Fathen & 98 & 106 & 144 & 496 \\
\hline Black nightshade & 18 & 33 & 3 & 78 \\
\hline Willow weed & 34 & 9 & 50 & 92 \\
\hline Beggars' ticks & 0 & 26 & 0 & 132 \\
\hline Broad-leaved dock & 3 & 4 & 15 & 7 \\
\hline Redroot & 0 & 0 & 1 & 31 \\
\hline Thorn apple & 0 & 0 & 0 & 25 \\
\hline Paper birch & 0 & 0 & 0 & 1 \\
\hline Ryegrass & 0 & 0 & 2 & 0 \\
\hline Rice grass & 0 & 0 & 0 & 1 \\
\hline Paspalum & 0 & 0 & 0 & 2 \\
\hline Total $^{3}$ & $224 \mathrm{a}$ & $280 \mathrm{a}$ & $277 \mathrm{a}$ & $1332 \mathrm{~b}$ \\
\hline
\end{tabular}

${ }^{1}$ Inside $=$ seeds found in grab samples from the top of the load.

${ }^{2}$ Outside $=$ seeds found in the debris on the outside of the truck.

${ }^{3}$ Totals followed by a different letter are significantly different $(\mathrm{P}<0.05)$.

Table 5 Number of seeds per kg of freshly chopped maize found in the samples collected from trucks being filled from the headland of the crop compared with those from the main crop area in 2014 .

\begin{tabular}{|c|c|c|c|c|}
\hline \multirow[b]{2}{*}{ Common name } & \multicolumn{2}{|c|}{ Inside $^{1}$} & \multicolumn{2}{|c|}{ Outside $^{2}$} \\
\hline & Main crop & Headland & Main crop & Headland \\
\hline Yellow bristle grass & 1 & 1 & 30 & 51 \\
\hline Barnyard grass & 0 & 0 & 4 & 3 \\
\hline Summer grass & 1 & 0 & 112 & 545 \\
\hline Smooth witchgrass & 7 & 4 & 3 & 1 \\
\hline Fathen & 5 & 4 & 270 & 87 \\
\hline Black nightshade & 0 & 0 & 176 & 1 \\
\hline Willow weed & 0 & 0 & 48 & 17 \\
\hline Broad-leaved dock & 0 & 0 & 4 & 7 \\
\hline Total $^{3}$ & $14 \mathrm{a}$ & $6 \mathrm{a}$ & $651 \mathrm{~b}$ & $714 \mathrm{~b}$ \\
\hline
\end{tabular}

${ }^{1}$ Inside $=$ seeds found in grab samples from the top of the load.

${ }^{2}$ Outside $=$ seeds found in the debris on the outside of the truck.

${ }^{3}$ Totals followed by a different letter are significantly different $(\mathrm{P}<0.05)$.

explanation for this larger seed number is that when the chopped maize misses the crate of the truck and instead hits the sides, the larger pieces will either ricochet off or fail to catch while the smaller and lighter debris, including damp weed seeds, are more likely to stick and remain. This concentration of seed also concerned John Austin Ltd and in 2015 they have modified their fleet of trucks to further minimise capture points (Lindy Bennett, John Austin Ltd, personal communication).
Similarly, trucks filled from the headland compared with the main crop area had higher numbers of seeds, particularly of yellow bristle grass, barnyard grass, fathen, redroot and thorn apple. This is most likely a reflection of the poorer weed control in the headland areas, especially in the first few rows where there is less shading from the maize plants and reduced competition for weeds. Other weeds appear to be less sensitive to shading and are found both in the headland 
and main crop areas. Beggars' ticks is generally associated with wet areas and drains and its presence in the headland samples will most likely be due to a drain on the edge of the field.

The concept of roadways being conduits for weed dispersal is not a new one but many vectors still remain to be identified and evaluated for propagule movement (Gelbard \& Belnap 2003; Christen \& Matlack 2006). Roadway dispersal falls into two main categories, passive and active. In passive dispersal the roadside environment simply provides a conduit of suitable habitat, and dispersal is by otherwise natural means such as seed set and movement (Christen \& Matlack 2009). In active dispersal other vectors, usually humans, are also involved (Clifford 1959; Bailleul et al. 2012). This study identifies the role of humans in the dispersal of weed seeds, thus in this case the roads are acting as active corridors for dispersal with the potential for moving the seeds great distances.

This study clearly identifies the transport of chopped maize along roadways as a potential dispersal mechanism for many weeds. Many different weed species were present in the chopped maize and the amount of loose debris that may be spread along the roadside could be considerable. However, apart from anecdotal observations by drivers of debris blowing off the trucks, other evidence of actual deposition along the roadside was not obtained. There was also no attempt to determine the distance that propagules may be moved on silage trucks. These should be the topics of ongoing study to fully quantify the role of roadways in the dispersal of weeds. It would appear that by highlighting the problem and at least determining the potential for spread, the agricultural contractors and others could initiate some positive steps to reduce this pathway as has happened already with John Austin Ltd. In Waikato they are using a dual approach. Firstly, as illustrated, they are reducing the quantity of debris on the outside of trucks through better training and modifications to the trucks' superstructure and secondly by taking more effort to manage yellow bristle grass in the headland areas of their maize crops.

\section{ACKNOWLEDGEMENTS}

This project was funded by the Ministry for Primary Industries through the Sustainable Farming Fund, Dairy NZ, Foundation for Arable Research, Yellow Bristle Grass Action Group, Waikato Regional Council and Horizons Regional Council. We also wish to thank John Austin Limited for allowing us to carry out the study using their trucks and for the assistance of Lindy Bennett in coordinating this. Maryann Pirie of AgResearch performed the statistical analyses and Amal Jose (Wintec) helped with the seed counts.

\section{REFERENCES}

AIMI 2014. AIMI - Survey of maize areas \& volumes - October 31, 2014. http://www.far. org.nz/mm_uploads/AIMI_Maize_Report_ FINAL_25_11_14.pdf(accessed 30 March 2015). Bailleul D, Ollier S, Huet S, Gardarin A, Lecomte J 2012. Seed spillage from grain trailers on road verges during oilseed rape harvest: an experimental survey. PloS one 7(3): e32752.

Christen DC, Matlack GR 2006. The role of roadsides in plant invasions: a demographic approach. Conservation Biology 20: 385-391.

Christen DC, Matlack GR 2009. The habitat and conduit functions of roads in the spread of three invasive plant species. Biological Invasions 11: 453-465.

Clifford HT 1959. Seed dispersal by motor vehicles. Journal of Ecology 47: 311-315.

James TK, Tozer KN, Rahman A 2009. Yellow bristle grass; a recent weed incursion in Waikato dairy pastures. Proceedings of the New Zealand Grassland Association 71: 39-42. James TK, Popay AI, Champion P, Grbavac N, Rhode B 2012. An illustrated guide to weed seeds of New Zealand. New Zealand Plant Protection Society, Lincoln, New Zealand. 126 pp. ISBN 978-0-473-22410-3.

Gelbard JL, Belnap J 2003. Roads as conduits for exotic plant invasions in a semiarid landscape. Conservation Biology 17: 420-432.

Lamoureaux SL, Bourdôt GW 2014. The potential distribution of yellow bristle grass (Setaria pumila) in New Zealand. New Zealand Plant Protection 67: 226-230. 